DOI 10.22460/jpmi.v1i3.219-228

\title{
ANALISIS PENGARUH SELF REGULATED LEARNING TERHADAP KEMAMPUAN BERPIKIR KREATIF MATEMATIS SISWA SMA
}

\author{
Asep Mauludin ${ }^{1}$, Adi Nurjaman ${ }^{2}$ \\ ${ }^{1,2}$ IKIP Siliwangi, Jl. Terusan Jenderal Sudirman, Cimahi, Jawa Barat, Indonesia \\ ${ }^{1}$ asepmauludin77@gmail.com, ${ }^{2}$ nurjaman@stkipsiliwangi.ac.id,
}

\begin{abstract}
This study aims to examine and describe the influence of self-regulated learning on the ability to think creatively mathematically high school students qualitatively descriptive. To get the data of research result used instrument in the form of creative thinking ability test and self regukated learning scale. sample of students of class X as many as 31 students. Qualitative analysis is done on the data of creative thinking ability and self-concept data. The instrument used is 5 questions of creative thinking ability test and 30 statements about self regulated learning. The results showed that self regulated learning affects the ability of students' mathematical creative thinking.
\end{abstract}

Keywords: Mathematical Creative Thinking, Self Regulated Learning

\begin{abstract}
Abstrak
Penelitian ini bertujuan untuk menelaah dan mendeskripsikan pengaruh self regulated learning terhadap kemampuan berpikir kreatif matematis siswa SMA secara deskriftif kualitatif. Untuk mendapatkan data hasil penelitian digunakan instrumen berupa tes kemampuan berpikir kreatif dan skala self regukated learning. sampel penelitian siswa kelas X sebanyak 31 siswa. Analisis kualitatif dilakukan terhadap data kemampuan berpikir kreatif dan data self-concept. Instrumen yang digunakan sebanyak 5 soal tes kemampuan berpikir kreatif dan 30 pernyataan mengenai self regulated learning. Hasil penelitian menunjukkan bahwa self regulated learning mempengaruhi kemampuan berpikir kreatif matematis siswa.
\end{abstract}

Kata Kunci: Kemampuan berpikir kreatif matematis, Self Regulated Learning

How to cite: Mauludin, A., \& Nurjaman, A. (2018). Analisis Pengaruh Self Regulated Learning Terhadap Kemampuan Berpikir Kreatif Matematis Siswa SMA. JPMI - Jurnal Pembelajaran Matematika Inovatif, 1 (2), 193-200.

\section{PENDAHULUAN}

Pada era modern seperti saat ini matematika disekolah bukan hanya sekedar mengajarkan siswa menghapalkan rumus dan menyelesaikan soal saja melainkan siswa dituntut untuk dapat mengembangkan kreativitasnya dalam mengembangkan pengetahuan yang ia miliki untuk kehidupannya sehari-harinya. Hal ini sejalan dengan pernyataan Amali, Komariah, \& Umar (2015) bahwa kreativitas perlu dikembangkan sejak dini karena diharapkan dapat menjadi bekal dalam menghadapi persoalan-persoalan dalam kehidupan. Sehingga siswa dapat memberdayakan kreativitasnya untuk mencari solusi dari permasalahan yang ia hadapi. Oleh karena itu kemampuan berpikir kreatif matematis sangat penting untuk dimiliki oleh siswa. 
Menurut Nurjaman \& Sari (2017) berpikir kreatif dapat didefinisikan sebagai aktivitas mental yang digunakan untuk membangun ide-ide baru. Sehingga sisiwa dapat mengembangkan iede dan gagasannya yang unik dalam berpikir mengadapi persoalan. Pentingnya kreativitas dalam matematika dikemukakan oleh Bishop (Lambertus, Arapu, \& Patih, 2013) yang menyatakan bahwa seseorang memerlukan dua keterampilan berpikir matematis, yaitu berpikir kreatif yang sering diidentikan dengan intuisi dan kemampuan berpikir analitik yang diidentikkan dengan kemampuan berpikir logis." Sedangkan Munandar (Azhari, 2013) berpendapat bahwa, berpikir kreatif merupakan kemampuan menentukan banyak kemungkinan jawaban terhadap suatu masalah, dimana penekanannya adalah pada kuantitas, ketepatan, dan keragaman jawaban. Makin banyak kemungkinan jawaban yang dapat diberikan maka makin kreatif seseorang. Sehingga kemampuan berpikir kreatif perlu dikembangkan siswa.

Berpikir kreatif matematis tidak serta merta timbul pada diri siswa tanpa adanya faktor -faktor yang mempengaruhinya. Siswa harus dibiasakan dalam mengembangkan kreativitasnya dalam pembelajaran matematika sehingga sedikit demi sedikit kemampuan berpikir kreatif matematis siswa tumbuh. Selain itu lingkungan belajar siswa harus membiasakan siswa mandiri dalam menyelesaikan persoalan belajarnya sehingga siswa memikirkan berbagai ide, gagasan, dan mengolaborasikan pengetahuan dan kemampuan yang ia miliki untuk menyelesaikan permasalahannya.

Kemampuan berpikir kreatif matematis siswa dapat dilihat dari ketercapaian indikator berpikir kreatif matematis itu sendiri. Filsaime (Nurqolbiah, 2016) mengungkapkan terdapat empat indikator kemampuan berpikir kreatif matematis yakni kelancaran, kelenturan, keaslian, dan elaborasi. Keempat indikator tersebut secara keseluruhan memuat bagaimana cara berpikir siswa dalam menghadapi suatu persoalan secara kreatif. Berpikir secara kreatif terhadap suatu persoalan matematis disini yakni siswa dapat memahami dan merinci persoalan yang ia hadapi untuk dicari berbagai alternatif penyelesaian serta menafsirkan berbagai macam kemungkinan jawaban dengan cara unik dengan mengolaborasikan kemampuan dan pengetahuan yang ia miliki (Hidayat, 2011; Dilla, Hidayat, \& Rohaeti, 2018). Uraian diatas berkaitan dengan definisi kemandirian yang dikemukakan oleh Schunk dan Zimmerman (Heris, Eti Rohaeti, \& Sumarmo, 2017) yaitu kemandirian belajar merupakan suatu proses belajar yang terjadi karena pengaruh dari pemikiran, perasaan, stategi dan perilaku siswa yang berorientasi pada hasil. Berdasarkan uraian diatas maka dapat diketahui bahwa kemandirian belajar terjadi karena pengaruh pemikiran dan strategi siswa dalam menghadapi persoalan dengan stategi penyelesaian berorientasi pada hasil. Dimana pemikiran atau cara berpikir siswa dalam menghadapi persoalan dan menyusun staregi penyelesaian erat kaitannya dengan kemampuan berpikir kreatif matematis.

Berdasarkan uraian diatas maka sangat penting kemampuan berpikir matematis dan kemandirian belajar untuk siswa miliki dan kembangkan. Oleh karena perlu dikaji pengaruh kemandirian belajar siswa terhadap kemampuan berpikir kreatif matematis siswa, sehingga selanjutnya dapat bermanfaat untuk mencari solusi pengembangan kemampuan berikir kreatif matematis siswa.

\section{METODE}

Metode yang digunakan dalam penelitian ini adalah metode kualitatif deskriptif dengan teknik korelasi dan regresi linier yaitu mencari hubungan dan pengaruh antara self regulated learning dengan kemampuan berpikir kreatif matematik siswa, serta menganalisa pengaruh self 
regulated learning terhadap kemampuan berpikir kreatif matematis siswa SMA secara menganalisa pengaruh self regulated learning dengan kemampuan berpikir kreatif matematik dari jawaban siswa secara kualitatif. Penelitian dilaksanakan di salah satu SMA Negeri di Kab. Bandung Barat dengan populasi sebanyak 31 siswa untuk dijadikan sampel penelitian. Instrumen variabel self regulated learning siswa sebanyak 30 butir pernyataan yang dilengkapi dengan 4 pilihan jawaban yaitu SS (Sangat Setuju), S (Setuju), TS (Tidak Setuju), STS (Sangat Tidak Setuju), yang telah di uji validitas isinya. Setiap pilihan jawaban yang diajukan memiliki skor antara 1 sampai 4 yaitu menggunakan skala likert (Lykert scale). Tes kemampuan berpikir kreatif yaitu berupa instrumen soal kemampuan berpikir kreatif matematis yang dibuat dalam bentuk uraian sebanyak 5 soal. Seluruh butir instrumen tersebut diujikan ke pada siswa dan selanjutnya diuji kelayakannya yaitu dengan menguji validitas, reliabilitas, tingkat kesukaran dan daya pembedanya.

\section{HASIL DAN PEMBAHASAN}

\section{Uji Korelasi dan Regresi}

Untuk melalukan uji korelasi dan regresi, maka terlebih dahulu dilakukan uji normalitas data self regulated learning dan kemampuan berpikir kreatif matematis. Karena syarat dari uji korelasi dan regresi adalah kedua data harus berdistribusi normal.

Tabel 1. Hasil Uji Normalitas Self Regulated Learning dan Kemampuan Berpikir Kreatif Matematis

\begin{tabular}{|c|c|c|c|}
\hline & \multicolumn{3}{|c|}{ Kolmogorov Smirnov } \\
\hline & Statistic & df & Sig. \\
\hline $\begin{array}{ll}\text { Self } & \text { Regulated } \\
\text { Learning } & \end{array}$ & .131 & 31 & .189 \\
\hline $\begin{array}{l}\text { Kemampuan Berpikir } \\
\text { Kreatif Matematis }\end{array}$ & .155 & 31 & .054 \\
\hline
\end{tabular}

Berdasarkan tabel diatas diketahui nilai signifikansi data self regulated learning sebesar 0,189 dan kemampuan berpikir kreatif matematis sebesar 0,054. Nilai signifikansi kedua data tersebut adalah $>0,005$, yaitu menunjukan bahwa kedua data tersebut berdistribusi normal. Untuk melihat seberapa kuat hubungan antara self-concept dan kemampuan berpikir kreatif, maka dilakukan uji korelasi Pearson dengan $\alpha=0,05$ dan hipotesisnya adalah

$H 0: \rho=0$

Ha: $\rho \neq 0$

keterangan:

korelasi antara self-concept dengan kemampuan berpikir kreatif 
Tabel 1. Hasil Uji Korelasi Self Regulated Learning Dan Kemampuan Berpikir Kreatif Matematis

\begin{tabular}{llll}
\hline & & $\begin{array}{l}\text { Self } \begin{array}{c}\text { Regulated } \\
\text { Learning }\end{array} \\
\text { Rerpikir } \\
\text { Kreatif } \\
\text { Matematis }\end{array}$ \\
\hline $\begin{array}{l}\text { Self Regulated } \\
\text { Learning }\end{array}$ & $\begin{array}{l}\text { Person } \\
\text { Correlation }\end{array}$ & 1 & $.541^{* *}$ \\
\cline { 2 - 4 } & Sig. (2-tailed) & .002 \\
\cline { 2 - 4 } $\begin{array}{l}\text { Kemampuan } \\
\text { Berpikir Kreatif } \\
\text { Matematis }\end{array}$ & $\begin{array}{l}\text { Person } \\
\text { Correlation }\end{array}$ & $.541^{* *}$ & 31 \\
\cline { 2 - 4 } & Sig. (2-tailed) & .002 & 1 \\
\hline
\end{tabular}

Dari Tabel 1, diperoleh hasil korelasi antara self regulated learning dan kemampuan berpikir kreatif siswa adalah $+0,544$ dan nilai signifikansi (sig) sebesar 0,000. Nilai korelasi (r) sebessar $0,544>0,5$ menunjukan bahwa korelasi antara self regulated learning dengan kemampuan berpikir kreatif matematis siswa tergolong kuat dan arah korelasi positif $(+)$ menunjukan bahwa semakin besar self regulated learning maka semakin besar pula kemampuan berpikir kratif matematis siswa. Sedangkan untuk nilai signifikansi $0,000<0,005$ menunjukan bahwa terdapat korelasi yang signifikan antara self regulated learning dengan kemampuan berpikir kreatif matematis siswa.

Untuk mengetahui besarnya pengaruh antara self regulated learning dengan kemampuan berpikir kreatif matematis maka dilakukan pengujian koefisien regresi dengan menggunakan analisis regresi linier. Analisis ini dilakukan untuk melihat pengaruh langsung dari self regulated learning siswa terhadap kemampuan berpikir kreatif siswa. Hipotesis yang diuji adalah:

Hipotesis penelitian untuk melihat self regulated learning siswa tentang matematika yaitu "Self regulated learning siswa mempengaruhi kemampuan berpikir kreatif matematis siswa"

Rumusan hipotesis uji perbedaan rerata self regulated learning adalah

$\mathrm{H} 0$ : Self regulated learning siswa tidak mempengaruhi kemampuan berpikir kreatif matematis siswa

H1 : Self regulated learning siswa tentang matematika mempengaruhi kemampuan berpikir kreatif matematis siswa.

Hasil analisis dapat dilihat pada tabel 2

Tabel 3. Hasil Analisis Regresi Self Regulated Learning dengan Kemampuan Berpikir Kreatif

\begin{tabular}{llll}
\hline \multirow{2}{*}{ Model } & \multicolumn{2}{l}{ Self Regulated Learning } & Sig. \\
\cline { 2 - 3 } & B & Std.Error & 0.000 \\
\hline $1 \quad$ (Constant) & 76.842 & 2.214 & 0.002 \\
$\begin{array}{l}\text { Kemampuan Berpikir } \\
\text { Kreatif Matematis }\end{array}$ & 0.881 & 0.225 & \\
\hline
\end{tabular}


Dari Tabel 2, dapat diketahui persamaan regresinya adalah $Y=76,842+0,881 x$ dan nilai signifikansi $0,002<0,05$. Berdasarkan persamaan regresinya menunjukan bahwa semakin besar nilai self regulated learning siswa, maka semaikin besar pula kemampuan berpikir kreatif matematis siswa. Sedangkan nilai signifikansi $0,002<0,005$ berarti bahwa Ho ditolak yang artinya bahwa secara signifikan self regulated learning siswa mempengaruhi kemampuan berpikir kreatif matematis siswa.

\section{Analisis Jawaban Siswa}

Hasil uji instrument kemampuan berpikir kreatif matematis materi trigonometri pada siswa adalah sebagai berikut:

\section{Analisis Soal 1}

Soal dengan indikator kelenturan yaitu sebagai berikut:

Seorang nelayan tengah berlayar mencari ikan dilaut. Karena cuaca buruk nelayan tersebut akan menepi ke pantai terdekat. Nelayan melihat puncak mercusuar yang ia ketahui sebelumnya berjarak 17 meter dari tepi pantai tersebut. Jika sudut elevasi perahu nelayan dengan puncak mercusuar adalah $10^{\circ}$ serta sudut elevasi dari puncak mercusuar ke tepi pantai $27^{\circ}$. Bantulah nelayan menemukan mencari jarak dari perahu ke tepi pantai dengan 2 cara berbeda!

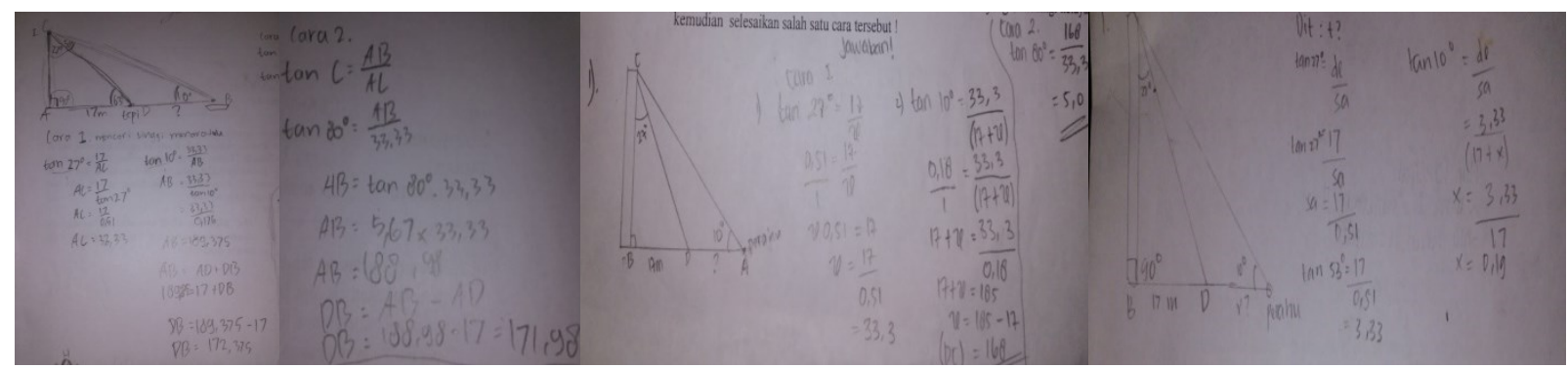

Gambar 1. Jawaban Siswa dengan nilai tinggi, sedang, rendah pada indikator kelenturan

Berdasarkan gambar 1, dapat terlihat perbandingan hasil jawaban siswa. Untuk jawaban siswa dengan nilai tinggi, siswa dapa menjawab soal dengan tepat. Itu dikarenakan siswa dapat mencari 2 penyelesaian soal tersebut. siswa dapat mendiagnosa pertanyaan dan siswa menguasai konsep yang diperlukan sehingga siswa dapat mudah mencari berbagai alternatif penyelesaian soal tersebut.

Sedangkan untuk jawaban siswa dengan skor sedang, siswa dapat memehami persoalan yaitu mencari berbagai alternatif jawaban. Siswa dapat menemukan 2 alternatif jawaban tetapi masih terdapat kesalahan. Siswa dapat menyelesaikan dengan baik alternatif jawaban 1, terlihat siswa dapat memahami konsep materi yang diperlukan. Tetapi siswa terdapat kekeliruan dalam pembulatan desimal, sehingga jawaban yang didapatkan tidak terlalu akuurat. Untuk alternatif jawaban yang kedua siswa kerjakan, siswa dapat melihat penyelesaian dari sudut pandang yang berbeda. Namun siswa tidak memahami konsep materi mana yang ia gunakan. Sehingga penyelesaian yang dihasilkan terdapat keslahan konsep.

Untuk jawaban siswa dengan skor terendah, siswa belum dapat menjawab soal dengan tepat, dikarenakan siswa hanya dapat menjawab persoalan dengan hanya satu cara. Siswa belum dapat mendiagnosa dan melihat permasalahan dai berbagai arah. Siswa hanya dapat berpikir terbuka terhadapt masalah. Dari jawaban siswa terlihat siswa dapat menggunkan konsep yang tepat dalam menyelesaikan soal. Namun tidak menguasai operasi hitungnya sehingga terdapat kekeliruan dalam mencari hasil. Siswa belum dapat berpikir terbuka dalam mendiagnosa permasalahan serta siswa kurang dalam pemahaman konsep serta operasi dasar menghitung. 


\section{Analisis Soal Nomor 2}

Soal dengan indikaor elaborasi yaitu sebagai berikut:

Sebuah jajar genjang ABCD memiliki panjang diagonal yaitu $11 \sqrt{3}$ dan $16 \mathrm{~cm}$, serta sudut yang dibentuk oleh kedua diagonal tersebut sebesar $30^{\circ}$. Gambarkanlah permasalahan diatas kemudian munculkan pertanyaan berkaitan dengan jajargenjang tersebut dan selesaikankan!

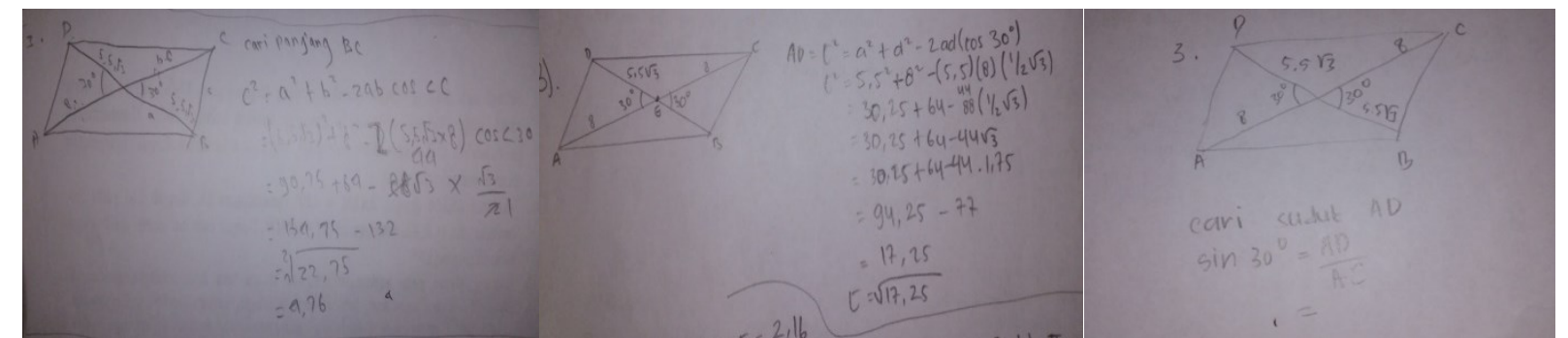

Gambar 2. Jawaban Siswa dengan nilai tinggi, sedang, rendah pada indikator berpikir luwes Berdasarkan gambar 4,siswa mampu menjawab permasalahan soal dengan tepat. Inisiatif siswa dalam menghadirkan permasalahan sangat tepat yakni mencari panjang BC, karena siswa paham dengan masalah yang ia ajukan dengan komponen jajar genjang yang diketahui sehingga siswa dengan mudah menyelesaikan permaslaahan. Pola pengerjaan soal siswa mencerminkan suatu kemandirian siswa dalam menyelesaikan masalah belajarnya, ia mampu menghadirkan ide dengan baik, mendiagnosa masalah, kemudian, dapat menentukan tujuan penyelesaian masalah.

Berdasarkan gambar 5, siswa belum menjawab soal dengan sempurna karena masih terdapat kekeliruan. Siswa dapat mendiagnosis soal dengan menghadirkan permaslahan yang tepat serta ide penyelesaian maslah yang tepat. Namun siswa kurang teliti dalam mendiagnosis permasalahan, yaitu siswa keliru dalam merinci komponen yang diketahui pada soal.

Berdasarkan gambar 6, siswa belum tepat dalam menentukan masalah. Karena belum diketahu maksud permasalahan yang diajukan. Siswa notasi sudut yang salah, walau maksudnya tepat sehingga peyelesaiannyapun siswa belum dapat tentukan.Siswa tidak dapat mendiagnosis soal dengan cermat, sehingga keliru dalam penyelesaian soal. Jawaban siswa menunjukan kekeliruan konsep, konsep yang digunakan harusnya pada segitiga siku-siku bukan segitiga sembarang. Siiswa kurang teliti dalam menggunakan konsep atau pengetahuan yang ia miliki.

\section{Analisis soal nomor 3}

Butir soal indikator originalitas adalah sebagai berikut:

Diketahui $\triangle K L M$ dengan $\angle K L M=120^{\circ}$. Perbandingan LK dengan LM yaitu 5:6. Terdapat titik $\mathrm{N}$ di KL sehingga $\angle K L N=\angle M L N$. Dengan cara mu sendiri uraikan cara mencari panjang LN!

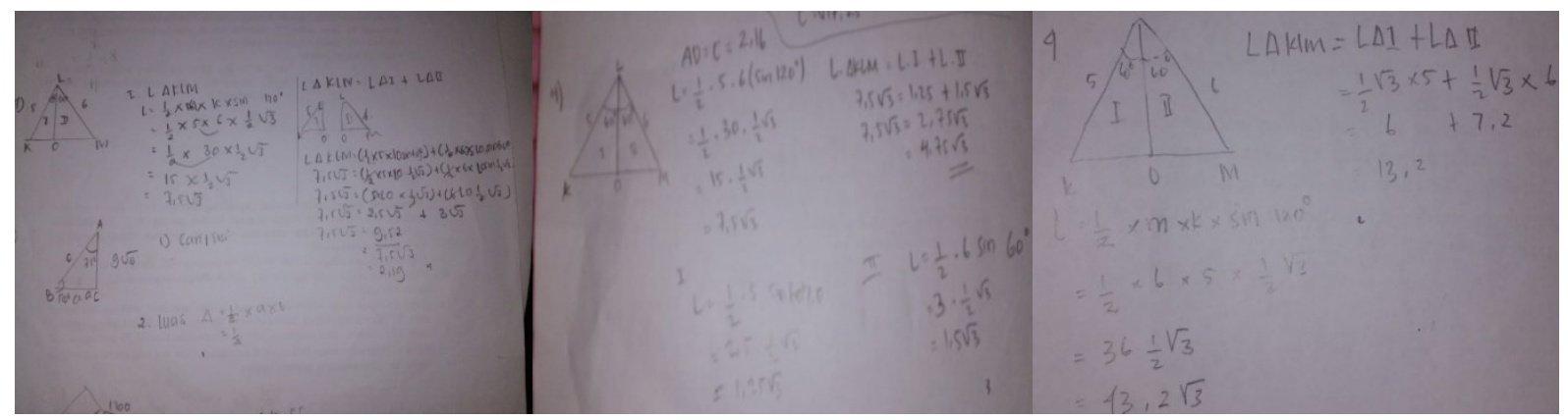

Gambar 3. Jawaban Siswa dengan nilai tinggi, sedang, rendah pada indikator originalitas 
Berdasarkan gambar 7 diketahui bahwa siswa dapat menyelesaikan soal tetapi terdapat kesalahan pada proses penyelesian akhir. Siswa telah dapat mendiagnosis soal dengan baik, itu dapat dilihat dari siswa dapat memahami maksud soal serta penyelesaian masalahnya. Siswa dapat menangkan ide yang ia punya tetapi sesuai dengan konsep yang tepat. Namun siswa belum teliti dalam perhitungan.

Berdasarkan gambar 7, dapat diketahui bahwa ide siswa dlam menyelesaikan soal sudah tepat. Namun berdasarkan jawaban, siswa terlihat kurang memahami ide yang ia kemukakan. Pada saat mencari komponen yang dibutuhkan siswa terlihat kurang terarah kepada tujuan akhir soal. Sehingga siswa salah dalam menentukan hasil dari soal tersebut.

Berdasarkan gambar 9 diketahui bahwa jawaban siswa ide yang dituangkan sudah mengarah pada inti permaslahan soal. Namun dalam mencari inti persoalan, siswa tidak dapat menggunkan ide yang ia gunakan dalam menyelesaikan masalah. Sehingga siswa kurang tepat dlam menyelesaikan permasalahan.

\section{KESIMPULAN}

Berdasarkan hasil dan pembahasan maka self regulated learning siswa berpengaruh terhadap kemampuan berpikir kreatif matematis siswa. Serta kesulitan siswa dalam menjawab soal kemampuan berpikir kreatif matematis siswa yaitu kurangnya pemahaman konsep siswa, siswa belum dapat mencapai indikator-indikator kemampuan berpikir kreatif matematis.

\section{DAFTAR PUSTAKA}

Amali, F., Komariah, K., \& Umar, U. (2015). PERBEDAAN KEMAMPUAN BERPIKIR KREATIF SISWA ANTARA PEMBELAJARAN YANG MENGGUNAKAN MODEL CREATIVE PROBLEM SOLVING DENGAN KONVENSIONAL. Jurnal PGSD Kampus Cibiru, 3(2).

Azhari. (2013). Peningkatan Kemampuan Berpikir Kreatif Matematika Siswa Melalui Pendekatan Kontruktivisme Di Kelas VII Sekolah Menengah Pertama (SMP) Negeri 2 Banyumas III. Jurnal Pendidikan Matematika, 7, 2-12.

Dilla, S. C., Hidayat, W., \& Rohaeti, E. E. (2018). Faktor Gender dan Resiliensi dalam Pencapaian Kemampuan Berpikir Kreatif Matematis Siswa SMA. Journal of Medives, 2(1), 129-136.

Heris, H., Eti Rohaeti, E., \& Sumarmo, U. (2017). Hard Skill dan Soft Skill Matematik Siswa. Bandung: Replika Aditama.

Hidayat, W. (2011). Meningkatkan Kemampuan Berpikir Kritis dan Kreatif Matematik Siswa Melalui Pembelajaran Kooperatif Think-Talk-Write (TTW) (Doctoral dissertation, Universitas Pendidikan Indonesia).

Lambertus, Arapu, L., \& Patih, T. (2013). Penerapan Pendekatan Open-Ended Untuk Meningkatkan Kemampuan Berpikir Kreatif Matematik Siswa SMP. Jurnal Pendidikan Matematika, 4(1), 73-82. 
Nurjaman, A., \& Sari, I. P. (2017). THE EFFECT OF PROBLEM POSING APPROACH TOWARDS STUDENTS' MATHEMATICAL DISPOSITION, CRITICAL \&amp; CREATIVE THINKING ABILITY BASED ON SCHOOL LEVEL. Infinity Journal, 6(1), 69. https://doi.org/10.22460/infinity.v6i1.223

Nurqolbiah, S. (2016). Peningkatan Kemampuan Pemecahan Masalah, Berpikir Kreatif dan Self-Confidence Siswa Melalui Model Pembelajaran Berbasis Masalah. JP3M (Jurnal Penelitian Pendidikan Dan Pengajaran Matematika), 2(2). 